of the pollen and with gene independence in the style no difficulties of dominance arise, and any new mutation will be at an immediate advantage since it will give compatibility with all others.

It might be argued that the morphological difference in heterostyled plants is the chief restriction on the number of incompatibility alleles; but the answer to this is found in Capsella grandiflora ${ }^{16}$, which is a species without heterostyly and with all the genetical characteristics of the heterostyled system.

Hypothetical systems constructed with the elements of both the known systems differently combined show that correct adjustment cannot be obtained in another way. For example, a system with haploid control of the pollen, and dominance of $S$ alleles in the style will fail, because an $S s$ plant will be selfcompatible since the $s$ pollen would grow in an $S s$ style. Also in an $s s \times S s$ pollination only $S$ pollen would be compatible. Such a system has so many faults that it could not last long if it ever arose. The reverse of this, that is, diploid control of the pollen and independence of $S$ alleles in the style, has the fault that $S s$ styles will reject the pollen of both $S s$ and $s s$ plants. It is true that with three or more alleles and special dominance relations between them a perpetuating system can be imagined; but this involves such unusual properties of the gene that it can be disregarded.

TABLE 3. A SUMMARY OF THE GENETICAL AND PHYSIOLOGICAL CONTROI OF INCOMPATIBILITY SHOWING THE RELATIONSHIP BETWEFN THEM.

\begin{tabular}{|c|c|c|c|}
\hline Morphology & Species & Physiology & Genetics \\
\hline \multirow{3}{*}{$\begin{array}{l}\text { Not hetero- } \\
\text { styled }\end{array}$} & $\begin{array}{c}\text { Oenothera } \\
\text { organensis }\end{array}$ & $\begin{array}{l}\text { (1) Independent } \\
\text { gene action in the } \\
\text { style but not in } \\
\text { the pollen }\end{array}$ & One gene \\
\hline & $\begin{array}{l}\text { Prunus avium } \\
\text { Nicotiana } \\
\text { sandera }\end{array}$ & $\begin{array}{l}\text { (2) Haploid pollen } \\
\text { control } \\
\text { (3) No dominance } \\
\text { (4) Protein reac- } \\
\text { tions }\end{array}$ & $\begin{array}{l}\text { Multiple } \\
\text { alleles }\end{array}$ \\
\hline & $\begin{array}{l}\text { Capsella } \\
\text { grandiflora }\end{array}$ & $\begin{array}{l}\text { (1) Co-ordinated } \\
\text { gene action in } \\
\text { style and pollen }\end{array}$ & \\
\hline $\begin{array}{c}\text { Hetero- } \\
\text { styled }\end{array}$ & $\begin{array}{l}\text { Primula } \\
\text { obconica } \\
\text { Primula } \\
\text { sinensis } \\
\text { Linum } \\
\text { grandifiorum }\end{array}$ & $\left\{\begin{array}{l}\text { (2) Diploid pollen } \\
\text { control } \\
\text { (3) Dominance } \\
\text { (4) (a) Protein } \\
\text { reactions } \\
\text { (b) Osmotic } \\
\text { pressure }\end{array}\right.$ & $\begin{array}{l}1-2 \text { genes } \\
2 \text { alleles }\end{array}$ \\
\hline
\end{tabular}

In their physiological control of incompatibility, plants without heterostyly and heterostyled plants differ in a way which reflects the genetical differences. This relationship is summarized in Table 3. Only one mechanism has been found in plants without heterostyly, and this appears to be an immunity type of reaction between specific proteins of the pollen and style. This alone has the possibility of variation necessary to meet the requirements of a large multiple allele series and the specificity necessary for the independent gene action in the style. In heterostyly it appears that this type of reaction is also present in some species; but another mechanism based on osmotic pressure has been found in Linum, and from the genetical evidence there is reason to believe that others exist. Thus a variety of different combinations of physiological and genetical mechanisms have been appropriately combined by selection, in favouring outbreeding modifications of the genetic system which have a long-term evolutionary advantage.
1 Mather, K., Nature, 153, 392 (1944).

2 Buller, A. H. R., Bot. Rev., 7, 355 (1941).

${ }^{3}$ Vandendries, R., and Brodie, H. J., La Cellule, 42, 165 (1933).

- Sears, E. R., Genetics, 22, 130 (1937)

5 Emerson, S., Genetics, 23, 190 (1938).

- Kakizaki, Y., Jap. J. Bot., 5, 133 (1930).

7 Emerson, S., Bot. Gaz., 101, 890 (1940).

Lewis, D., Proc. Roy. Soc., B, 131, 13 (1942).

- East, E. M., Genetics, 17, 175 (1932).

${ }^{10}$ Atwood, S. S., J. Amer. Soc. Agron., 34, 353 (1942)

${ }^{11}$ Crane, M. B., and Lewis, D., J. Genet, 43, 31 (1942).

12 Stout, A. B., and Chandler, C., Science, 94, 118 (1941).

13 Livermore, J. R, and Johnstone, F. E., Amer. Potato J., 17, 170 (1940).

${ }^{14}$ Lewis, D., J. Genet., 45, 171 (1943).

${ }^{15}$ Lewis, D., Ann. Bot., 7, 115 (1943).

${ }^{2}$ Riley, H. P., Genetics, 21, 24 (1936).

\section{FACTORS IN THE PRODUCTION OF HONEY}

\section{BY E. B. WEDMORE, C.B.E.}

$\mathrm{M}^{\mathrm{R}}$ R. JOHN PRYCE-JONES, who is a physical chemist, discusses "Some Problems Associated with Nectar, Honey and Pollen" in forty-five pages of the Journal of the Linnean Society (Pt. 2, 1942-43). This critical résumé will be most valuable to future workers in the same field. A strong case can be made out for further work. The honey bee in Great Britain contributes, by its pollinating activities alone, $£ 4,000,000$ a year to the economy of fruit-growing and seed production. An annual expenditure on research of $£ 4,000$ would show a return of $10: 1$ if it only increased efficiency by one per cent per annum; incidentally, in the U.S.S.R. the figure is $\$ 40,000,000$ a year.

Future investigators will need to study far more than the fifty-six principal references cited by $\mathrm{Mr}$. Pryce-Jones. How hard it is to persuade experimenters that the last thing they must do is make an experiment, and the last but one is to record all the circumstances and features that may affect interpretation and application of the results ! Many of the researches cited lose permanent value through failure in the latter duty. The conflicting and partial conclusions reached are faithfully dealt with by Pryce-Jones, but many are open to further criticism. For example, there is the investigator who correlates percentage of nectar in fireweed with the humidity of the atmosphere, expressing the results to four significant figures; evidently the arithmetic took charge of the investigator. Having regard to the very large variation disclosed of sugar content with humidity, the meaningless nature of figures given for sugar content without reference to humidity is at once apparent ; yet the records abound with them.

Based on the capacity of the bee's honey sac, a round figure of 20,000 flights is quoted for the collection of one pound of nectar. This is converted to 80,000 for honey. Taking the sugar content of honey at 80 per cent, this puts that of the nectar at 20 per cent. Now in the first place, the bee scarcely ever arrives home with a honey sac anything like full; again, a full sac will carry nearly three times the figure quoted; and the figure of 20 per cent is near the lower limit of what interests the bee, and it will generally find a much more profitable source to work upon. It is certain that the figure of 80,000 flights is too high for profitable harvesting. Incidentally, the figure of $200 \mathrm{lb}$. given as the honey 
which a colony consumes in bee production per season and for its own needs before it can show any surplus is on the low side for a really profitable colony.

Miss A. D. Betts has shown that bees can transfer a maximum amount of sugar from a feeder on the hive in a given time when the sugar content of the syrup is about 40 per cent. Thicker syrup is taken too slowly, and thinner syrup carries too little sugar. In the field, the bee spends the larger part of its time travelling to and from the source and from flower to flower. Now if the time occupied in gathering nectar is fixed as part of the whole, Miss Betts' figure is likely to apply; but $I$ infer that for a given strength of nectar the bee will prefer the source in which the nectaries have the larger content, for she will then economize in time of travel. If, however, the sugar content of the nectars varies, it will pay the bee to work at a nectar more dense than that named provided there is more sugar in each nectary ; that is, it is the sugar content rather than the nectar content of the nectary that is important and up to limits in excess of 40 per cent. In very dry weather, sugar content far exceeds any figures quoted by Pryce-Jones ; indeed, a supersaturated solution is found in very dry weather. In 1942 in Kent and elsewhere, the bees could not work on the limes because the nectar was crystallized.

There is a great deal yet to be done to solve the problems associated with nectar production. No fewer than five theories are quoted and discussed; only one touches upon the relationship of sugar production to soil content; that deals with nitrogen content, but leaves potassium and phosphorus out of account. Pryce-Jones remarks that while the nectary acts as a semi-permeable membrane, holding back the proteins in the sap, no explanation has yet been offered of the diffusion of a dilute solution of sugar in the sap into a more concentrated solution in the nectary.

Pryce-Jones himself has shown that the thixotropy characterizing a very few honeys, notably that from ling and from manuka, is due to the presence of about 1 per cent of a protein. Honey usually contains but a trace of any protein. This particular protein may be extracted and when added to another and liquid honey causes it to become thixotropic. It is difficult to attach much weight to the criticism by Paul 'Espinasse that it has yet to be proved that the protein is of vegetable origin and not added by the bee. Why should all bees add so unfortunate a protein only to those particular nectars, introducing a property which may cause them later to starve in the apparent presence of plenty ? It would appear to be far more probable that in these plants a small quantity of a certain protein passes through from the sap. There is room for further investigation of this protein and especially its molecular weight.

In the study of the relationship between the honey crop and the weather, much confusion has been introduced through failure to recognize the large variation of sugar content of nectar when observing changes of hive weight. Certain correlations with weather conditions, however, have been obtained. These indicate that in summer and early autumn, temperatures are generally adequate, but humidity tends to be too low; hence a wide variation in temperature with its wide variation in relative humidity tends to bring the sugar contents within the range for efficient collection for some period of the day, and perhaps to assist in nectar secretion. In the spring, however, temperatures may be inadequate, also hours of sunshine; hence greater importance is attached to temperatures and especially to temperature variation, the latter bringing about periods of suitable temperature and corresponding with periods of intermittent but more adequate sunshine. The conditions are somewhat different as between clay and sandy soils. In studying atmospheric conditions in the summer and autumn, however, there is a correlation factor above 50 per cent outstanding against unknown factors, showing the supreme importance of sources of nectar.

The bee-keeper desires a more continuous succession of adequate sources than he can yet find in any one place; also less unintentional interference by those concerned with agriculture and horticulture. Surely, having regard to the very large contribution to these industries made by the bee-keeper, referred to in the opening paragraph above, it is time that the Ministry of Agriculture assumed official responsibility for beekeeping, and secured some correlation of the interests of these several industries. A co-operative study, for example, of the benefits to be derived by the several parties by increased use of appropriate sweet clovers. and incidentally of Zofka clover, should provide a very large return for a small expenditure by the Ministry. Any programme should be examined by practical bee-keepers and agriculturists as well as by scientific men if it is to be really effective and profitable. On the practical side, there should be no lack of assistance if only someone in authority would bring the parties together.

\section{OBITUARIES}

\section{Dr. J. Argyll Campbell}

Argyil Campberl was a most distinguished student at Edinburgh, gaining very many university prizes and honours. He unfortunately suffered early in his career a catarrhal infection which resulted in deafness, a handicap which he most bravely overcame so far as his output of research was concerned, but which prevented him gaining full recognition of his worth. As professor of physiology at the Government School of Medicine, Singapore, he did valuable work, and in the War of 1914-18 prevented the authorities from substituting an equal weight of sweet potatoes (a watery food) for rice in the workers' ration. As one of a small commission, he was largely instrumental in securing the addition of the province of Trengannu to the Malay States.

Returning to Great Britain, Campbell joined the Department of Applied Physiology at the National Institute of Medical Research, where, until ill-health led to his recent retirement, he carried out very valuable research work. An inquiry with me into the protective effect of water-proof clothing against exposure, such as results from shipwreck, resulted in the adoption by the Ministry of Transport of a suitable suit for merchant seamen in the present War; a quarter of a million such suits have been issued, and high value is given to these as the result of experience.

Campbell developed a simple method of measuring the tension of oxygen and carbon dioxide in tissue spaces, and made the interesting discovery that high pressures of oxygen, such as produce oxygen poisoning, occasion a high tension of carbon dioxide in these spaces. The power of hæmoglobin to combine with and carry carbon dioxide from the tissues is thwarted by its saturation with oxygen. He carried out most 